\title{
Long-term impacts of livestock grazing on Chihuahuan Desert rangelands
}

\author{
JOSEPH M. NAVARRO, DEE GALT, JERRY HOLECHEK, JIM MCCORMICK, AND FRANCISCO MOLINAR
}

Joseph Navarro is a Rangeland Management Specialist with the BLM in the Roswell Field Office 2909 W. 2nd St. Roswell, N.M. 88201 and a Graduate Research Assistant, Department of Animal and Range Sciences, New Mexico State University; Dee Galt is a private range consultant, Las Cruces, NM 88005; Jerry Holechek is a range science professor, Dept. of Animal and Range Sciences, New Mexico State University, Las Cruces, NM 88003; Jim McCormick is assistant field manager, Las Cruces Field Office, USDI, Bureau of Land Management, Las Cruces, NM 88005; and Francisco Molinar is a range animal ecology professor, School of Veterinary Medicine and Animal Science, Autonomous University of Juarez, Chihuahua, Mexico.

Abstract

Rangeland ecological condition was monitored over a 48 year period on 41 sites on Bureau of Land Management rangelands scattered across 6 counties in southwestern New Mexico. All sites were grazed by livestock during the study period. Sampling occurred in 1952, 1962, 1982, 1992, 1997, 1998, and 1999. A modified Parker 3 step method in conjunction with Dyksterhuis quantitative climax procedures were used to determine rangeland ecological condition. At the end of the 48 year study period (1952-1999), the average rangeland ecological condition score across study sites was the same $(P>0.05)$ as the beginning of the study (39\% versus $41 \%$ remaining climax vegetation, respectively). Major changes $(P>0.05)$ in rangeland condition occurred within the study period due to annual fluctuations in precipitation. Ecological condition scores increased in the 1980s and early 1990s due to above average precipitation. However, drought in the early to mid 1950's and again in the mid to late 1990's caused rangeland condition scores to decline. At the end of the study (1997-1999), 38\% of the sites were in late seral ecological condition, compared to an average of $25 \%$ in the 1952 to 1982 period. The amount of rangeland in late seral ecological condition increased while the amount of rangeland in mid seral and early seral condition decreased in the 1990s compared to the 1952-1962 period. The average percent cover of black grama (Bouteloua eriopoda Torr.) and tobosa (Hilaria mutica Buckley), the primary forage grasses in the Chihuahuan Desert, were the same $(P>$ 0.05 ) in 1952 and 1999 . Over the 48 year study period, the average cover of shrubs including honey mesquite (Prosopis glandulosa Torr.) showed no change $(P>0.05)$. However major increases in honey mesquite basal cover occurred on 1 site and creosotebush (Larria tridentata [Pursh] Nutt.) increased on another. Grazing intensity was evaluated during the last 3 years of study $(1997,1998,1999)$. Overall grazing use of forage across sites and years averaged $34 \%$ or conservative. Our research shows controlled livestock grazing is sustainable on Chihuahuan Desert rangelands receiving from $26-35 \mathrm{~cm}$ annual precipitation.

Key Words: Rangeland condition, succession, drought, grazing management, plant ecology

This project is \#14226910A970011, Monitoring Range Ecological Condition \& Trend Studies in the Northern Chihuahuan Desert Grasslands located in Southwestern New Mexico. Funding for this research was provided by the USDIBureau of Land Management and the New Mexico Agricultural Experiment Station.

Manuscript accepted 13 Sept. 2001

\section{Resúmen}

La condición ecológica de los pastizales del desierto chihuahuense se determinó en un estudio que abarcó 48 años y que se llevó a cabo en 41 sitios dentro de 6 condados del suroeste de Nuevo México. El estudio se realizó en terrenos administrados por la Agencia para el manejo de Tierras de los Estados Unidos. Los sitios estuvieron bajo pastoreo durante todos los años de duración del trabajo. Los muestreos se realizaron en 1952, 1962, 1982, 1992, 1997, 1998, y 1999. Se utilizó una modificación del sistema de 3 pasos de Parker y los procedimientos de Dyksterhuis para cuantificar el clímax. La finalidad fué determinar la condición ecológica de los pastizales. Al final de los 48 años del estudio (1952- 1999) se determinó que el promedio de la condición ecológica, al considerar todos los sitios, fue la misma $(P>0.05)$ que la existente al inicio de los trabajos en $1952(39 \%$ contra $41 \%$ del remanente de la vegetación del climax, respectivamente). Los cambios mas notorios en la condición ecológica durante los años del estudio $(P>0.05)$ se debieron a las fluctuaciones de la precipitación pluvial. Los rangos de la condición ecológica aumentaron en la década de los años ochenta y al inicio de los noventa debido al incremento de la precipitación. Sin embargo, la sequía al inicio y durante la primera mitad de los años cincuenta y nuevamente durante la segunda mitad y hasta el fin de los noventa, provocó que disminuyeran los porcentajes de la condición ecológica. En la parte final del trabajo (1997-1999), el $\mathbf{3 8 \%}$ de los sitios se encontraron bajo condición ecológica de buena a excelente, en comparación con el $25 \%$ bajo esas condiciones durante el período de 1952 a 1962. Al comparar los resultados de los años noventa con el período de 1952 a 1982, la cantidad de pastizales en estado ecológico bueno a excelente se incrementó y la cantidad en estado pobre a regular disminuyó. Los promedios de cobertura de los zacates mas representativos del desierto chihuahuense como navajita negro (Bouteloa eripoda Torr.) y Toboso (Hilaria mutica Buckley) fueron los mismos (P > 0.05) en 1952 y en 1999. Durante los 48 años del estudio, el promedio de cobertura de plantas leñosas como el mezquite (Prosopis glandulosa Torr.) no mostró cambios mayores (P > 0.05). Sin embargo, se detectaron incrementos importantes en la cobertura basal de Prosopis en uno de los sitios y de la gobernadora (Larrea tridentata [Pursh] Nutt.) en otro. Por otra parte, se evaluó la intensidad de pastoreo durante los últimos 3 años (1997, 1998, 1999). La utilización promedio del forraje al contabilizar todos los sitios y los años fue conservadora o del $34 \%$ del total. Nuestra investigación indica que el pastoreo controlado es viable en pastizales del desierto chihuahuense, aunque solo se reciban niveles de precipitación pluvial de 260 a $350 \mathrm{~mm}$ anuales. 
Published quantitative information is lacking on the general trend in ecological condition for different types of public rangelands in New Mexico and other western states. Information is available on range condition and trend for many individual public grazing allotments throughout the western states. Various government reports have indicated range condition on public lands is improving but these reports are somewhat vague and subjective regarding how range condition was measured and classified (United States Department of Interior 1999). Studies are needed that quantitatively characterize long-term changes in rangeland vegetation in different range biomes in response to climatic conditions and livestock grazing management. This information is also needed because of increased social pressure to remove livestock from public rangelands and emphasis on non-consumptive rangeland uses (Wuerthner 1990, Donahue 1999).

Recent studies in the Chihuahuan Desert of southern New Mexico have shown that controlled livestock grazing can be biologically sustainable, economically cost effective, and compatible with most wildlife species (Holechek et al. 1994, Nelson et al. 1997, Winder et al. 2000). However evaluations are needed over broad areas to determine the effects of livestock grazing as it has actually occurred. There is considerable concern among many conservation groups that ranchers may not be using sustainable grazing practices (Wuerthner 1990).

The 1950s drought had great impact on Chihuahuan Desert rangelands (Buffington and Herbel 1965). However detailed scientific evaluation of the impacts of this event on Chihuahuan Desert vegetation has been reported only from the USDA Jornada Experimental Range in southcentral New Mexico (Buffington and Herbel 1965, Herbel et al. 1972, Herbel and Gibbens 1996). Drought and post drought vegetation responses on the Jornada Experimental Range however may not be completely representative of the Chihuahuan Desert in southern New Mexico.

The objective of our study was to evaluate long term (48 years) trend in vegetation composition using 41 locatable Parker sites in the Chihuahuan Desert of southwestern New Mexico. Complete data is available for 7 years of sampling (1952, $1962,1982,1992,1997,1998,1999)$ on 22 of these sites. A secondary objective was to evaluate grazing intensity on the study sites in late spring of 1998, 1999, and 2000 using procedures of Holechek and Galt (2000).

\section{Methods}

\section{Study Area}

In 1952 the Bureau of Land Management initiated a study to examine long term trend in range vegetation in the Chihuahuan Desert of southwestern New Mexico. This study involved use of the Parker 3 step method (Parker 1951). Parker transects on the various sites were evaluated in 1952, 1962, 1982, 1992, 1997, 1998, and 1999.

The majority of the study area lies within the northern end of the Chihuahuan Desert $\left(106^{\circ} 52^{\prime} 30^{\prime \prime} \mathrm{W}, 32^{\circ} 32^{\prime} 30 \mathrm{~N}\right)$. The study area is bounded by Texas and Mexico to the south, Arizona to the west, and is traversed by the Rio Grande on the eastern side. This region is administered by the USDI-Bureau of Land Management Mimbres and Caballo Resource Areas in the Las Cruces District. The Mimbres Resource Area includes Hidalgo, Grant, Luna, and Dona Ana counties. The Caballo Resource Area includes Otero and Sierra counties. There are 2.7 million ha of BLM administered public land intermingled with 5.3 million ha of private, State trust, Native American, and other Federal lands in this 6 county area.

The area is characterized by an arid to semiarid continental climate, with mild winters and hot summers. Most of the study area receives from $26-35 \mathrm{~cm}$ annual precipitation. Annual fluctuations range from a low of $5 \mathrm{~cm}$ to a high of over 50 $\mathrm{cm}$. Over half of the annual precipitation arrives as rainfall during July, August, and September. The average frost free season exceeds 200 days and extends from April to November. The average annual temperature in the area is about $20^{\circ} \mathrm{C}$. During the summer months, daytime temperatures may exceed $38^{\circ} \mathrm{C}$. Through the year, a daily range of $17^{\circ} \mathrm{C}$ or more is common. Both the rainfall distribution and temperature regime favor warm season perennial plants.

Typical landform includes rugged and steep fault-block mountain ranges, broad basins, and volcanic uplands. Elevations on BLM-administered public land range from a low of approximately $1,067 \mathrm{~m}$ in the southern Mesilla Valley to a high of over $2,438 \mathrm{~m}$ in some of the mountain ranges. Average elevation is about 1,372 $\mathrm{m}$. Our study sites are primarily in the broad basins.

The vegetation varies greatly in its diversity and herbage yields due to differences in elevation, climate, soils, and topography. Plant communities include desert grasslands, mixed desert shrublands, desert shrublands, mountain brush, and pinon-juniper/oak woodland. Our study sites were confined primarily to the desert grasslands with a few desert shrubland sites. The 7 major range sites based on USDA-Natural Resources Conservation Service guides are gravelly, igneous hills, sandy, loamy, gravelly loam, malpais, and clayey.

\section{Sampling Procedures}

Forty-one different study sites were used in this analysis. Generally the goals in site selection were to select accessible flat grassland areas with uniform soils in medium size to large pastures $1.4 \mathrm{~km}$ from water. Site selection was based on ease of access, distance from water, soil type, vegetation type, size of pasture, and terrain. Ecotones where soil types and vegetation were in transition were avoided. All study sites were located on uniform soils, flat terrain and in uniform, discreet plant communities. One site had 1 transect, 26 sites had 2 transects, 10 sites had 3 transects and 4 sites had 5 transects. All sites were within $1.2 \mathrm{~km}$ to $1.6 \mathrm{~km}$ of permanent water, and were grazed during the period of the study. The 41 sites we studied are well scattered over 6 counties in southwestern New Mexico.

A modification of the Parker 3 step method was used to evaluate trends in vegetation cover on each site (Parker 1951). Permanent 30.5-m line transects were accurately located from existing steel rebar. Readings were taken and recorded at $30.5 \mathrm{~cm}$ intervals using a loop $1.91-\mathrm{cm}$ in diameter along a tape stretched between the 2 permanent rebar stakes. Data recorded along the transect included presence of all herbaceous plants and shrubs rooted within the loop. There were no recordings of multiple plants within the loop. Evaluations were conducted during the dormant period of the year (late fall through early spring). Transect data were collected for the years of 1952-54, 1962-64, 1982, 1992, 1997, 1998, and 1999. In all years of study, data were collected by professionals with range science training. Dr. Dee Galt, a private range consultant with 30 years experience in the USDA-Natural Resources Conservation Service, supervised all data collection in the 1992 to 1999 period.

Plant cover in our study is more of an 
index than an absolute value. Loop sampling tends to overestimate cover for small plants (Hutchings and Holmgren 1959). However, as a cover index, loop sampling is reliable for detecting vegetation changes over time (Smith 1962).

Range ecological condition scores were calculated from current USDA Natural Resources Conservation Service New Mexico range site guides using the Dyksterhuis (1949) procedure. Cover was used instead of biomass in calculating scores. Cover and biomass indices gave similar ecological condition scores across several sites on the Chihuahuan Desert Rangeland Research Center in southcentral New Mexico (Molinar 1999).

During late spring (May, June) in the last 3 years of study, grazing intensity was evaluated on all study sites using procedures of Holechek and Galt (2000). This approach involves assessment of forage stubble heights, remaining seed stalks, and percentage of plants grazed.

Comparisons among years for ecological condition scores and plant cover were analyzed by analysis of variance using a completely randomized design with study sites as replicates. The least significant difference mean separation procedure was used to compare means in time if analysis of variance indicated a significant difference (Steel and Torrie 1980).

\section{Results and Discussion}

Average rangeland ecological condition score was not different $(\mathrm{P}>0.05)$ between 1952 and $1999(n=22)$ (Table 1). For the 22 sites supporting complete data sets, the 1950 s drought caused a drop in range condition, but steady improvement occurred from 1962 to 1992.

Possibly the most reliable assessment of change in ecological condition through time on our study areas is the comparison of the average of the first 3 years sampled in our study $(1952,1962,1982)$ with the last 3 years $(1997,1998,1999)$ across the 22 sites with complete data (Table 1). On this basis the condition score averaged $33.7 \%$ for the 1952-1982 period compared to $37.0 \%$ for the 1997-1999 period, with no significant $(\mathrm{P}=0.36)$ differences. Therefore, we conclude that no change has occurred in rangeland ecological condition between early years and the final years of our study.

Shifting climatic conditions in southwestern New Mexico explain the major fluctuations in rangeland ecological condition from 1952 to 1999 (Table 2). The 1950s were characterized by extreme drought receiving $73 \%$ of the 100 year average (National Oceanic and Atmospheric Administration 1999). In contrast, precipitation in the 1980 s was $12 \%$ above the 100 year average.

Climatic conditions in southwestern New Mexico in the 1992 to 1999 period were near normal (Table 2). Four years were wet $(1992,1993,1997,1999)$, one year was dry (1995), and 3 years were near average $(1994,1996,1998)$ (National Oceanic and Atmospheric Administration 1999). Above average growing season precipitation (May through September) occurred in 1992, 1996, 1997, and 1999.
In 1994 and 1995 growing season precipitation was well below average. Annual precipitation averaged $29.74 \mathrm{~cm}$ for the 1992-1999 period compared to the long term average of $30.07 \mathrm{~cm}$. From a historical standpoint, the 1980s and 1990s were the wettest decades in New Mexico during the past 100 years while the 1950 s were the driest.

Rangeland ecological condition scores for individual sites showed considerable fluctuation in the 1997-1999 period (Table 1). We attribute this to both sampling disparities and climatic variability. Because fewer plants were encountered along the transects in low ecological con-

Table 1. Ecological condition scores (USDA-National Resources Conservation Service method) on 41 sites on Bureau of Land Management rangelands in the Chihuahuan Desert of New Mexico over a 48 year period (1952-1999).

\begin{tabular}{|c|c|c|c|c|c|c|c|c|}
\hline Range site & County & 19521 & 1962 & 1982 & 1992 & 1997 & 1998 & 1999 \\
\hline & $\cdots$ & & & $-(\%$ & - & -- & - & -5 \\
\hline Clayey & Grant & 47 & 62 & 52 & 67 & 70 & 70 & 74 \\
\hline Loamy & Luna & 24 & 9 & 21 & 32 & 15 & 23 & 26 \\
\hline Sandy & Dona Ana & 14 & 13 & 19 & 23 & 15 & 17 & 27 \\
\hline Shallow Sandy & Dona Ana & 26 & 44 & 14 & 48 & 43 & 6 & 16 \\
\hline Clayey & Luna & 56 & 43 & 43 & 56 & 38 & 26 & 50 \\
\hline Clayey & Grant & 65 & 26 & 46 & 50 & 51 & 51 & 43 \\
\hline Gravelly & Sierra & 35 & 33 & 51 & 47 & 48 & 49 & 53 \\
\hline Clayey & Hidalgo & 38 & 8 & 22 & 25 & 19 & 18 & 16 \\
\hline Clayey & Hidalgo & 57 & 20 & 49 & 79 & 55 & 46 & 53 \\
\hline Clayey & Hidalgo & 44 & 46 & 40 & 43 & 33 & 32 & 52 \\
\hline Loamy & Hidalgo & 48 & 44 & 40 & 47 & 35 & 45 & 50 \\
\hline Loamy & Hidalgo & 49 & 21 & 21 & 36 & 23 & 34 & 31 \\
\hline Sandy & Hidalgo & 30 & 12 & 22 & 21 & 28 & 32 & 31 \\
\hline Sandy & Hidalgo & 11 & 8 & 8 & 14 & 16 & 8 & 8 \\
\hline Clayey & Dona Ana & 51 & 46 & 43 & 41 & 40 & 45 & 43 \\
\hline Draw & Luna & 63 & 36 & 66 & 69 & 66 & 60 & 63 \\
\hline Loamy & Grant & 15 & 13 & 16 & 16 & 17 & 26 & 31 \\
\hline Sandy & Luna & 30 & 35 & 37 & 41 & 35 & 43 & 56 \\
\hline Clayey & Luna & 56 & 28 & 47 & 49 & 43 & 44 & 43 \\
\hline Hills & Hidalgo & 32 & 18 & 10 & 27 & 26 & 20 & 43 \\
\hline Loamy & Hidalgo & 42 & 31 & 46 & 47 & 41 & 50 & 61 \\
\hline Gravelly & Dona Ana & 32 & 23 & 23 & 20 & 20 & 15 & 20 \\
\hline Gravelly & Luna & 25 & 48 & --- & 66 & 73 & 60 & 60 \\
\hline Shallow Sandy & Sierra & --- & 37 & 73 & 62 & 61 & 62 & 57 \\
\hline Shallow Sandy & Otero & --- & 68 & --- & 80 & 70 & 65 & 84 \\
\hline Loamy & Sierra & --- & 21 & 55 & 58 & 63 & 63 & 71 \\
\hline Breaks & Sierra & --- & 46 & 57 & 48 & 57 & 46 & 53 \\
\hline Hills & Sierra & --- & 46 & 58 & 51 & 52 & 42 & 59 \\
\hline Gravelly & Sierra & --- & 55 & 50 & 54 & 57 & 55 & 55 \\
\hline Clayey & Hidalgo & --- & 20 & 37 & 55 & 58 & 55 & 53 \\
\hline Hills & Hidalgo & --- & 45 & 43 & 53 & 48 & 51 & 51 \\
\hline Gravelly & Luna & --- & 35 & 33 & 60 & 40 & 48 & 43 \\
\hline Hills & Hidalgo & --- & 41 & 50 & 49 & 48 & 45 & 51 \\
\hline Hills & Hidalgo & --- & 53 & 30 & 27 & 18 & 19 & 13 \\
\hline Gravelly & Luna & --- & 33 & 51 & 50 & 60 & 51 & 65 \\
\hline Shallow Sandy & Dona Ana & --- & 48 & 30 & 37 & 16 & 21 & 41 \\
\hline Gravelly & Sierra & --- & 34 & 42 & 44 & 38 & 34 & 56 \\
\hline Sandy & Sierra & --- & 39 & 43 & 50 & 45 & 28 & 44 \\
\hline Loamy & Otero & --- & 17 & 45 & 55 & 50 & 45 & 68 \\
\hline Shallow Sandy & Hidalgo & --- & 48 & --- & 53 & 34 & 37 & 59 \\
\hline Sandy & Dona Ana & -- & $-\cdots$ & --- & --- & --- & 58 & 65 \\
\hline $\begin{array}{l}\text { Average } \bar{x} \\
\text { (All sites) }\end{array}$ & & & $34^{\mathrm{c}}$ & $39^{b c}$ & $46^{\mathrm{ab}}$ & $42^{\mathrm{ab}}$ & $39^{b}$ & $47^{\mathrm{a}}$ \\
\hline $\begin{array}{l}\text { Average } \frac{}{x} \\
\text { (First } 22 \text { sites) }\end{array}$ & & $39^{\mathrm{ab}}$ & $28^{\mathrm{c}}$ & $33^{\mathrm{bc}}$ & $41^{\mathrm{a}}$ & $36^{\mathrm{ab}}$ & $34^{b}$ & $41^{\mathrm{a}}$ \\
\hline
\end{tabular}

a,b,c Means within rows with different superscripts differ at $\mathrm{P}<0.05$. 
Table 2. Annual precipitation (PPT-cm) for 10 year intervals in southwestern new Mexico for the 1950-1999 period (National Oceanic and Atmospheric Administration 1999). ${ }^{1}$

\begin{tabular}{lrcccccccc}
\hline \hline Year & PPT & Year & PPT & Year & PPT & Year & PPT & Year & PPT \\
\hline & $(\mathrm{cm})$ & & $(\mathrm{cm})$ & & $(\mathrm{cm})$ & & $(\mathrm{cm})$ & & $(\mathrm{cm})$ \\
1950 & 14.05 & 1960 & 25.30 & 1970 & 19.41 & 1980 & 23.80 & 1990 & 37.87 \\
1951 & 15.80 & 1961 & 28.04 & 1971 & 23.60 & 1981 & 30.86 & 1991 & 44.25 \\
1952 & 14.99 & 1962 & 31.72 & 1972 & 37.59 & 1982 & 26.83 & 1992 & 37.72 \\
1953 & 9.70 & 1963 & 23.88 & 1973 & 23.93 & 1983 & 35.53 & 1993 & 30.53 \\
1954 & 15.57 & 1964 & 21.36 & 1974 & 33.12 & 1984 & 42.95 & 1994 & 29.67 \\
1955 & 25.60 & 1965 & 28.80 & 1975 & 30.10 & 1985 & 40.28 & 1995 & 21.49 \\
1956 & 12.12 & 1966 & 24.66 & 1976 & 25.30 & 1986 & 44.37 & 1996 & 27.79 \\
1957 & 31.98 & 1967 & 28.93 & 1977 & 27.13 & 1987 & 30.76 & 1997 & 32.74 \\
1958 & 41.43 & 1968 & 27.56 & 1978 & 36.25 & 1988 & 36.47 & 1998 & 28.22 \\
1959 & 23.98 & 1969 & 26.64 & 1979 & 29.36 & 1989 & 22.33 & 1999 & 28.37 \\
$\frac{\mathrm{x}}{1953}$ & 20.52 & & 26.70 & & 28.58 & & 33.63 & & 31.88 \\
\hline
\end{tabular}

${ }^{1}$ Locations monitored include Afton, Alamogordo, Animas, Antelope Wells, Buckhorn, Cliff, Columbus, Deming, Glenwood, Hachita, Hillsboro, Jornada, Las Cruces, Lordsburg, Orogrande, Redrock, Truth or Consequences, White Sands, White Signal, and Whitewater.

dition sites, more annual variability occurred in vegetation composition. Some sites had major fluctuations in broom snakeweed (Gutierrizea sarothrae Pursh.) populations during 1997-1999 period. Broom snakeweed is a short lived, poisonous, perennial half shrub whose populations can fluctuate greatly from year to year with weather (Pieper and McDaniel 1989). Wet winters and springs promote broom snakeweed establishment.

Our data provide only limited insight into the various rangeland plant successional models (Holechek et al. 2001), because large time gaps occurred between some of the assessments on the sites. In addition, grazing management changes on the sites were not well documented across time. We do note that there was a tendency for sites in early seral stages to show improvement during the 1962-1999 period (Table 1). Nine of the 13 sites in an early seral stage improved to mid seral or late seral condition. This provides support for the theories of Dyksterhuis (1949) that some degraded rangelands can improve through natural plant succession under favorable climatic conditions and controlled livestock grazing.

Black grama (Bouteloua eriopoda Torr.), the primary decreaser forage in southern New Mexico, showed no difference $(\mathrm{P}>0.05)$ in basal cover between 1952 and $1999(\mathrm{n}=22)$ (Table 3). Tobosa (Hilaria mutica Buckley) and total perennial grass cover did not differ $(\mathrm{P}>0.05)$ between 1952 and $1999(\mathrm{n}=22)$. No increase in shrub basal cover $(\mathrm{P}>0.05)$ occurred over the 4 year period $(\mathrm{n}=22)$ (Table 3). Honey mesquite (Prosopis glandulosa Torr.) cover was the same (P > $0.05)$ in 1952 and $1999(n=22)$. However, 2 sites had major increases in shrub basal cover when the 1952-1962 period was compared to the 1997-1999 period. Honey mesquite was invading 1 site while creosotebush (Larrea tridentata [Pursh] Nutt.) was invading another.

Black grama and other perennial grasses had a sharp increase $(\mathrm{P}<0.05)$ in basal

\section{Table 3. Variation in mean basal cover (\%) of primary plant species found on 41 different sites on Bureau of Land Management rangelands in the Chihuahuan Desert of New Mexico over a 48 year period (1952-1999).}

\begin{tabular}{|c|c|c|c|c|c|c|c|}
\hline \multirow[b]{3}{*}{ Plant category } & \multicolumn{7}{|c|}{ First 22 sites } \\
\hline & \multicolumn{7}{|c|}{ Year } \\
\hline & $1952^{1}$ & 1962 & 1982 & 1992 & 1997 & 1998 & 1999 \\
\hline & \multicolumn{7}{|c|}{ 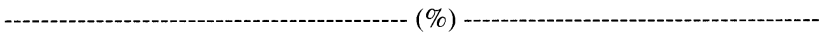 } \\
\hline Tobosa & $4.0^{\mathrm{a}}$ & $2.3^{\mathrm{a}}$ & $4.9^{\mathrm{a}}$ & $10.2^{\mathrm{a}}$ & $3.4^{\mathrm{a}}$ & $3.0^{\mathrm{a}}$ & $3.3^{\mathrm{a}}$ \\
\hline Black Grama & $1.5^{\mathrm{a}}$ & $1.1^{\mathrm{a}}$ & $1.6^{\mathrm{a}}$ & $4.7^{\mathrm{a}}$ & $1.2^{\mathrm{a}}$ & $1.4^{\mathrm{a}}$ & $1.5^{\mathrm{a}}$ \\
\hline Burrograss & 2.8 & 1.5 & 2.3 & 3.4 & 0.6 & 0.9 & 0.9 \\
\hline Aristida spp. & 0.2 & 0.0 & 0.0 & 1.5 & 0.2 & 0.3 & 0.2 \\
\hline Other perennial grasses & $3.4^{\mathrm{a}}$ & $2.3^{\mathrm{a}}$ & $3.3^{\mathrm{a}}$ & $6.2^{b}$ & $1.6^{\mathrm{a}}$ & $1.6^{\mathrm{a}}$ & $2.4^{\mathrm{a}}$ \\
\hline Annual grasses & 0.0 & 0.0 & 0.4 & 0.2 & Trace & 1.2 & 1.4 \\
\hline Total grasses & $11.9^{\mathrm{a}}$ & $7.2^{\mathrm{a}}$ & $12.5^{\mathrm{a}}$ & $26.2^{\mathrm{b}}$ & $7.2^{\mathrm{a}}$ & $8.4^{\mathrm{a}}$ & $9.7^{\mathrm{a}}$ \\
\hline Total forbs & $2.5^{\mathrm{a}}$ & $6.6^{\mathrm{a}}$ & $1.9^{\mathrm{a}}$ & $7.9^{\mathrm{b}}$ & $2.8^{\mathrm{a}}$ & $2.2^{\mathrm{a}}$ & $0.6^{\mathrm{a}}$ \\
\hline Honey mesquite & 0.2 & 0.1 & 0.3 & 0.6 & Trace & 0.0 & 0.2 \\
\hline Broom snakeweed & 0.4 & 0.4 & 1.7 & 2.0 & Trace & 0.2 & 0.2 \\
\hline Other shrubs & 0.3 & 0.1 & 0.8 & 1.2 & 0.1 & Trace & 0.1 \\
\hline Total shrubs & 0.9 & 0.6 & 2.8 & 3.8 & 0.2 & 0.3 & 0.5 \\
\hline \multirow[t]{3}{*}{ Total basal cover } & $15.3^{\mathrm{a}}$ & $14.4^{\mathrm{a}}$ & $17.2^{\mathrm{a}}$ & $37.9^{\mathrm{b}}$ & $10.2^{\mathrm{a}}$ & $10.9^{\mathrm{a}}$ & $10.8^{\mathrm{a}}$ \\
\hline & \multicolumn{7}{|c|}{ All 41 sites } \\
\hline & \multicolumn{7}{|c|}{ Year } \\
\hline Plant category & & 1962 & 1982 & 1992 & 1997 & 1998 & 1999 \\
\hline Tobosa & \multicolumn{7}{|c|}{ - } \\
\hline Black Grama & & $2.8^{\mathrm{a}}$ & $2.8^{\mathrm{a}}$ & $9.0^{\mathrm{b}}$ & $1.9^{\mathrm{a}}$ & $2.1^{\mathrm{a}}$ & $2.9^{\mathrm{a}}$ \\
\hline Burrograss & & 1.6 & 2.1 & 2.5 & 0.7 & 0.8 & 0.9 \\
\hline Aristida spp. & & Trace & 0.3 & 2.2 & 0.4 & 0.4 & 0.4 \\
\hline Other perennial grasses & & $2.8^{\mathrm{a}}$ & $2.6^{\mathrm{a}}$ & $6.9^{b}$ & $2.0^{\mathrm{a}}$ & $1.8^{\mathrm{a}}$ & $2.5^{\mathrm{a}}$ \\
\hline Annual grasses & & Trace & 0.2 & 0.1 & Trace & 0.7 & 0.9 \\
\hline Total grasses & & $8.9^{\mathrm{a}}$ & $11.4^{\mathrm{a}}$ & $27.6^{\mathrm{b}}$ & $7.1^{\mathrm{a}}$ & $7.7^{\mathrm{a}}$ & $9.7^{\mathrm{a}}$ \\
\hline Total forbs & & $4.6^{\mathrm{a}}$ & $2.5^{\mathrm{a}}$ & $5.2^{\mathrm{b}}$ & $1.8^{\mathrm{a}}$ & $1.6^{\mathrm{a}}$ & $0.6^{\mathrm{a}}$ \\
\hline Honey mesquite & & Trace & 0.3 & 0.3 & Trace & Trace & 0.2 \\
\hline Broom snakeweed & & 0.4 & 1.6 & 1.6 & Trace & 0.2 & 0.3 \\
\hline Other shrubs & & Trace & 1.2 & 1.3 & 0.3 & 0.4 & 0.7 \\
\hline Total shrubs & & 0.4 & 3.1 & 3.2 & 0.3 & 0.4 & 0.7 \\
\hline Total basal cover & & $13.9^{\mathrm{a}}$ & $17.0^{\mathrm{a}}$ & $36.0^{\mathrm{b}}$ & $9.2^{\mathrm{a}}$ & $9.7^{\mathrm{a}}$ & $11.0^{\mathrm{a}}$ \\
\hline
\end{tabular}

\footnotetext{
${ }^{\mathrm{ab}}$ Means within rows with different superscripts differ at $\mathrm{P}<0.05$.
} spacing of rainfall events. Storms that did occur generally were well distributed through July and August, and seldom involved more than $0.76 \mathrm{~cm}$ precipitation. This moisture was quickly lost to evapora-

cover during the 1982-1992 period, and then sharply declined $(\mathrm{P}<0.05)$ in the 1992-1999 period $(n=22)$ (Table 3). We speculate the dry summers in 1994 and 1995 were more damaging to perennial grasses than in other decades because the long run of wet years in the 1980s and 1990s may have reduced plant resistance to drought. Well above average precipitation in the 1990-1992 period elevated perennial grass basal cover above what plant root systems could support in normal years. Plant rooting depths and root to shoot ratios may have been altered by the exceptionally wet conditions. This could have altered the plant's ability to cope with the return to more normal precipitation conditions. The severity of consecutive summer droughts in 1994 and 1995 may have also been accentuated by the

\section{.}


Table 4. Percentages of study sites (41) in southwestern New Mexico classified as either severely grazed, heavily grazed, moderately grazed, conservatively grazed, lightly grazed or ungrazed by livestock in 1998, 1999, and 2000.

\begin{tabular}{|c|c|c|c|c|c|c|}
\hline \multirow[b]{2}{*}{ Year } & \multicolumn{5}{|c|}{ Grazing intensity } & \multirow[b]{2}{*}{ Ungrazed } \\
\hline & Severe & Heavy & Moderate & Conservative & Light & \\
\hline & & & & & & \\
\hline 1998 & 0 & 7 & 38 & 0 & 48 & 7 \\
\hline 1999 & 2 & 18 & 41 & 27 & 5 & 7 \\
\hline 2000 & 0 & 10 & 27 & 29 & 32 & 2 \\
\hline $\bar{x}$ & 1 & 12 & 35 & 19 & 28 & 5 \\
\hline
\end{tabular}

tion. Generally about $2.54 \mathrm{~cm}$ of rain, concentrated within a 1 week period, is needed to initiate growth of desert grasses such as black grama and tobosa (Canfield 1939). This did not occur in 1994 or 1995 in most parts of southwestern New Mexico. Research on the Chihuahuan Desert Rangeland Research Center north of Las Cruces indicated that forage production in 1994 and 1995 was only $18 \%$ of the 32 year average (Holechek et al. 2000).

Based on tree ring data, extended droughts lasting 5-12 years have occurred about every 50 to 60 years in the southwestern United States (Meko et al. 1995). The last extended drought occurred in the 1941 to 1956 period. Twelve of the 15 years had below average precipitation. Some climatologists believe the southwestern United States is again entering an extended dry period (Fleck 1998).

Grazing intensity across the 41 sites was considered to be conservative (34\% use of forage) (Table 4). Seven sites showed repeated heavy grazing during the 3 years grazing intensity was measured. Nineteen of the 41 study sites were lightly or conservatively stocked.

Our interviews with permittees using the study sites indicated ranchers are better informed on the benefits of conservative stocking than they were 8 years ago (1992). About 1 half of the ranchers interviewed were consciously attempting to implement conservative stocking on their grazing allotments.

Table 5. Percentages of Bureau of Land Management study sites (41) in southwestern New Mexico in different ecological condition categories in 1952, 1962, 1982, 1992, and 1999.

\begin{tabular}{lcccc}
\hline \hline Year & $\begin{array}{l}\text { Excellent } \\
\text { (climax) }\end{array}$ & $\begin{array}{c}\text { Good } \\
\text { (late seral) }\end{array}$ & $\begin{array}{c}\text { Fair } \\
\text { (mid seral) }\end{array}$ & $\begin{array}{c}\text { Poor } \\
\text { (early seral) }\end{array}$ \\
\hline $1952^{1}$ & 0 & 26 & 52 & 22 \\
1962 & 0 & 24 & 44 & 32 \\
1982 & 0 & 24 & 50 & 26 \\
1992 & 5 & 32 & 48 & 15 \\
1997 & 0 & 32 & 45 & 23 \\
1998 & 0 & 30 & 46 & 24 \\
1999 & 2 & 51 & 35 & 12 \\
\hline
\end{tabular}

Only 22 sites were evaluated in 1952

None of our study sites had any type of shrub control applied during the 48 year study period. Additional water development had occurred within several study pastures but not near our study sites. Data in New Mexico Agricultural Experiment Station reports indicated there has been a doubling of water developments on southern New Mexico rangelands over the past 40 years (Torell et al. 2000). Only a slight increase in new fencing has occurred since 1960 .

Total livestock numbers for $\mathrm{New}$ Mexico counties are reported annually by the New Mexico Agricultural Statistics Service (2000). In the 6 sampled counties total beef cattle numbers steadily increased from 193,310 during 1960 to 251,350 head in 1980. However, cattle numbers since 1980 have declined to around 220,000 head in 2000 .

\section{Management Implications}

Our study showed that $38 \%$ of Bureau of Land Management rangeland sites we monitored in southwestern New Mexico were in late seral or climax ecological condition in the 1997-1999 period compared to $25 \%$ in the $1952-1982$ period (Table 5). We believe our study sites are fairly representative of BLM rangelands in southwestern New Mexico. Several studies reviewed by Holechek et al. (2001) show that late seral condition rangeland

(a) 
Donahue, D. L. 1999. The western range revisited: Removing livestock from public lands to conserve biodiversity. Univ. of Oklahoma Press, Norman, Okla.

Fleck, J. 1998. Studying droughts legacy. Albuquerque J. Sunday, February 1, 1998.

Hector, D.P. 1987. The decline of the aplomado falcon in the United States. American Birds 41:381-389.

Herbel, C. H. and R. P. Gibbens. 1996. Postdrought vegetation dynamics on arid rangelands in southern New Mexico. N. Mex. Agr. Exp. Sta. Bull. 776.

Herbel, C.H. and W.L. Gould. 1995. Management of mesquite, creosote bush, and tarbush with herbicides in the northern Chihuahuan Desert. New Mexico Agr. Exp. Bull. 775 .

Herbel, C. H., F. N. Ares, and R. A. Wright. 1972. Drought effects on a semidesert grassland range. Ecol. 53:1084-1093.

Holechek, J. L. 1992. Financial benefits of range management practices in the Chihuahuan Desert. Rangelands 14:279-282.

Holechek, J. L. and D. Galt. 2000. Grazing intensity guidelines. Rangelands 22:11-14.

Holechek, J. L., A. Tembo, A. Daniel, M. J. Fusco, and M. Cardenas. 1994. Long term grazing influences on Chihuahuan desert rangeland. Southwestern Naturalist 39:342-349.

Holechek, J. L., R. D. Pieper, and C. H. Herbel. 2001. Range management: principles and practices. $4^{\text {th }}$ Edition. Prentice-Hall Inc., Upper Saddle River, N. J.

Holechek, J. L., M. G. Thomas, D. Galt, and F. Molinar. 2000. Conservative and moderate stocking effects on Chihuahuan Desert forage production. Proc. West. Sect. Amer. Soc. Anim. Sci. 51:257-260.

Houston, W. R. and R. R. Woodward. 1966. Effects of stocking rates on range vegetation and beef cattle production in the northern Great Plains. U.S. Dept. Agr. Tech. Bull. 1357.

Hughes, L. E. 1982. A grazing system for the Mojave desert. Rangelands 2:17-18.
Hutchings, S. and R. C. Holmgren. 1959. Interpretation of loop-frequency data as a measure of plant cover. Ecol. 4:668-677.

Johnson, W. M. 1953. Effect of grazing intensity upon vegetation and cattle gains on ponderosa pine-bunchgrass ranges of the front range of Colorado. U.S. Dept. Agr. Circ.

Klipple, G. E. and D. F. Costello. 1960. Vegetation and cattle responses to different intensities of grazing on shortgrass ranges of the central Great Plains. U.S. Dept. Agr. Circ. 929.

Martin, S. C. 1975. Stocking strategies and net cattle sales on semi-desert range. U.S. Dept. Agr. For. Serv. Res. Pap. RM-146.

Martin, S. C. and D. R. Cable. 1974. Managing semidesert grass-shrub ranges: Vegetation responses to precipitation, grazing, soil texture, and mesquite control. U.S. Dept. Agr. Tech. Bull. 1480.

Meko, D., C. W. Stockton, and W. R. Boggess. 1995. The tree-ring record of severe sustained drought. Water Res. Bul. 31:789-801.

Molinar, F. 1999. Effect of honey mesquite cover and soil depth on forage production in the Chihuahuan Desert. Ph.D. Thesis, New Mexico State University, Las Cruces, N.M.

National Oceanic and Atmospheric Administration. 1999. Climatological data annual summary, New Mexico, 1999. National Climatic Data Center, Asheville, N.C.

Nelson, T., J. L. Holechek, R. Valdez, and M. Cardenas. 1997. Wildlife numbers on late and mid seral Chihuahuan Desert rangelands. J. Range Manage. 50:593-599.

New Mexico Agricultural Statistics Service. 2000. New Mexico Agricultural Statistics, 1960 to 2000. New Mexico Dept Agr., Las Cruces, N.M.

Parker, K. W. 1951. A method for measuring trend in range condition in national forest range condition in national forest ranges Fort Collins, Colo. U.S. Dept. of Agr., Forest Service, Rocky Mountain Forest and Range Exp. Sta.
Paulsen, H. A. and F. N. Ares. 1962. Grazing values and management of black grama and tobosa grasslands and associated shrub ranges of the southwest. U.S. Dept. Agr. Tech. Bull. 1270

Pearson, H. A. 1973. Calculating grazing intensity for maximum profit on ponderosa pine range in northern Arizona. J. Range Manage. 26:277-278.

Pieper, R. D. and K.C. McDaniel. 1989. Ecology and management of broom snakeweed. New Mexico Agr. Exp. Bull. 751.

Quigley, T. M., J. M. Skovlin, and J. P. Workman. 1984. An economic analysis of two systems and three levels of grazing on ponderosa pine-bunchgrass range. J. Range Manage. 37:309-312.

Smith, J. G. 1962. An appraisal of the loop transect method for estimating root crown area changes. J. Range Manage. 15:72-78.

Steel, R. G. D. and J. H. Torrie. 1980. Principles and procedures of statistics. $2^{\text {nd }}$ Ed. McGraw-Hill Book Co., New York

Torell, L.A., J. M. Hawkes, and S.A. Bailey. 2000. Range livestock cost and return estimates from New Mexico, 1997. New Mexico Agr. Exp. Sta. Res. Rep. 738.

United States Department of Interior (USDI). 1999. Public land statistics. U.S. Department of Interior. Bureau of Land Manage.

Valentine, K. A. 1970. Influence of grazing intensity on improvement of deteriorated black grama range. New Mexico Agr. Exp. Stn. Bull. 553

Winder, J. A., C. C. Bailey, M. Thomas, and J. Holechek. 2000. Breed and stocking rate effects on Chihuahuan Desert cattle production. J. Range Manage. 53:32-38.

Wuerthner, G. 1990. The price is wrong. Sierra 25:38-48. 